\title{
Sources and Doses of Nitrogen Associated with Inoculation with Azospirillum brasilense Modulate Growth and Gas Exchange of Corn in the Brazilian Amazon
}

\author{
Juscelino Gonçalves Palheta ${ }^{1^{*}}$, Ricardo Shigueru Okumura ${ }^{2}$, Gerson Diego Pamplona Albuquerque ${ }^{1}$, Diana Jhulia \\ Palheta de Sousa ${ }^{1}$, Jessica Suellen Silva Teixeira ${ }^{1}$, Myriam Galvão Neves ${ }^{1}$, Wagner Romulo lima Lopes Filho ${ }^{3}$, Luma \\ Castro de Souza ${ }^{1}$ and Cândido Ferreira de Oliveira Neto ${ }^{1}$ \\ ${ }^{1}$ Institute of Agrarian Sciences, Laboratory of Biodiversity Studies of Upper Plants, Federal Rural University of Amazonia, \\ Campus Belém, Pará, Brazil \\ ${ }^{2}$ Federal Rural University of Amazonia, Campus Parauapebas, Pará, Brazil \\ ${ }^{3}$ Federal Rural University of Amazonia, Campus Belém, Pará, Brazil \\ *For correspondence: juscegoncalves@ hotmail.com; juscelinoagronomo@gmail.com \\ Received 06 April 2021 Accepted 25 May 2021; Published 10 July 2021
}

\begin{abstract}
The specific objective of the study was to evaluate effect of inoculation with Azospirillum brasilense and nitrogen (N) doses on vegetative growth and gas exchange in Zea mays L. The experimental design adopted was the completely randomized, in a 422 factorial scheme, in the following way: four doses of $\mathrm{N}$ (0 60120 and $180 \mathrm{~kg} \mathrm{ha}^{-1}$ of N), two sources of $\mathrm{N}$ (common urea and urease inhibitor-treated urea) and absence and presence of inoculation with $A$. brasilense, with four replications. The evaluations were made for vegetative growth of the plant (plant height, stem diameter, leaf area, number of leaves, dry mass of stem, root, leaves and aerial part and total dry mass) and photosynthesis, stomatal conductance, transpiration, internal carbon, relationship between internal and external carbon and content of chloroplast pigments. The application of $\mathrm{N}$ provided an improvement in plant growth, and, in general, the dose of $180 \mathrm{~kg} \mathrm{ha}^{-1} \mathrm{~N}$ associated with A. brasilense, promoted an increase in stem diameter, photosynthesis, stomatal conductance, transpiration and internal carbon ratio of the corn. The treatment with urease inhibitor, greatly promoted the stem diameter, transpiration, $\mathrm{Ci} / \mathrm{Ca}$ ratio and chlorophyll (Chl) a, b, total compared to urea treatment. The inoculation of the corn seeds with the bacteria and the use of $\mathrm{N}$ fertilization, regardless of the source, promoted an improvement in the vegetative growth of the hybrid, improving the vegetative growth and the physiological responses of corn when applied to the highest dose of $180 \mathrm{~kg} / \mathrm{ha}$ N. (C) 2021 Friends Science Publishers
\end{abstract}

Keywords: Growth promoting bacteria; Nitrogen fertilization; Photosynthesis; Urease inhibitor

\section{Introduction}

Corn (Zea mays L.) is a cereal crop that belongs to the Poaceae family and to the genus Zea. It has a great economic importance on the world as its grains are used in animal and or human diets, and also as thickeners, adhesive and in the production of oils. Brazil is the world's third biggest corn producer, after the USA and China, and the second largest exporter of Coêlho (2018). However, to achieve high yields, high doses of nitrogen $(\mathrm{N})$ are necessary since the soil does not have an adequate supply to satisfy the needs of the crop (Galindo et al. 2016), making the $\mathrm{N}$ fertilization one of the most expensive input in the production process (Souza et al. 2019).

The indiscriminate use of mineral fertilizer may affect negatively soil fertility, and cause problems to the environment, such as soil acidification, environmental pollution and reduction of microbial activity; thus, plantgrowth promoting bacteria appear as an alternative to reduce production costs and promote agricultural sustainability (Vijayalakshmi et al. 2019). Because $\mathrm{N}$ is fundamental in the metabolism by actively participating in amino acids, proteins, nucleic acids, amides and coenzymes (Munareto et al. 2018). It is the nutrient absorbed in greater quantity by corn and the one that most limits production, exercising functions in the essential components of the plant cell, involved in the increment of grain productivity. However, the Brazilian soils present, in their majority, low content of available $\mathrm{N}$, making $\mathrm{N}$ fertilization an indispensable practice (Dartora et al. 2013). In the Brazilian Amazon region, farmers have adapted the recommendations for fertilizing corn grown in the south of the country, since research data for the crop is scarce, so the doses of fertilizers may have been overestimated and or underestimated.

To cite this paper: Palheta JG, RS Okumura, GDP Albuquerque, DJ Palheta de Sousa, JSS Teixeira, MG Neves, WRIL Filho, L Castro de Souza, C Ferreira de Oliveira Neto (2021). Sources and doses of nitrogen associated with inoculation with Azospirillum brasilense Modulate growth and gas exchange of corn in the brazilian amazon. Intl J Agric Biol 26:349-358 
There is a need for studies that intensify the efficiency improvement in the use of $\mathrm{N}$, aiming at a more sustainable production. An alternative is the use of diazotrophic bacteria of the genus Azospirillum due to their ability to reduce the use of chemical fertilizers, therefore improving the activities of soil microorganisms and enhancing the growth of the root system of plants (Vogel and Fey 2016). When associated with the rhizosphere, the bacteria provide biological nitrogen fixation by breaking down the $\mathrm{N}_{2}$ molecule available in the atmosphere, making it assimilable to plants in the form of ammonia (Galindo et al. 2019), as well as it enhances the absorption of phosphorus, $\mathrm{N}$ and micronutrients, and promotes the production of auxins, cytokinins, gibberellins and ethylene (Marngar and Dawson 2017).

Despite the benefits of inoculation with Azospirillum, the bacteria cannot supply the $\mathrm{N}$ amount required for corn; therefore, the crop needs to be supplemented with $\mathrm{N}$ fertilizers, mainly in the form of urea (IFA 2019). The advantage of usinf urea as high $\mathrm{N}$ source is that it has, high solubility, ease of mixing with other sources and lower cost of $\mathrm{N}$. However, it presents high losses due to ammonia volatilization $\left(\mathrm{NH}_{3}\right)$, particularly in countries with tropical regions such as in Brazil, where there is a prevalence of high temperatures (Frazão et al. 2014).

One of the alternatives to minimize $\mathrm{N}$ losses is the treatment of urea with a substance that inhibits the activity of the enzyme urease, the so-called $\mathrm{N}$-(nbutil) triamide thiophosphate (NBPT). The addition of the inhibitor to urea reduces the $\mathrm{NH}_{3}$ volatilization by around $60 \%$, increasing the efficiency of use of $\mathrm{N}$ and the productivity of the crop (Cantarella et al. 2008). However, there is a lack of studies that define the necessary dose of $\mathrm{N}$ in combination with Azospirillum spp. to obtain maximum corn yield, so it is essential to determine the potential of using the bacteria in combination with NBPT in corn, therefore, evaluating the efficiency of the use of $\mathrm{N}$ in crop productivity (Galindo et al. 2019). Thus, the hypothesis of this work is that the inoculation with $A$. brasilense combined with the source and dose of $\mathrm{N}$, improves the vegetative growth processes and the physiological behavior of corn hybrid. The specific objective of the study was to evaluate effect of inoculation with $A$. brasilense and $\mathrm{N}$ doses with common urea and urease inhibitor on growth and gas exchange in corn in the Brazilian Amazon.

\section{Materials and Methods}

\section{Area characterization and soil analysis}

The experiment was carried out in a greenhouse located at the Institute of Agricultural Sciences of the Federal Rural University of the Amazon, Belém, Brazil. Its geographic coordinates are $48^{\circ} 26^{\prime} 18.0^{\prime \prime}$ West longitude of Greenwich and $1^{\circ} 27^{\prime} 17.3$ " South latitude. According to the Köppen (1918), the climate is Afi-type, with an average rainfall of at least $60 \mathrm{~mm}$. The Sandy-loam textured soil used in the experiment was collected at a depth of 0 to $20 \mathrm{~cm}$, and classified as a dystrophic Yellow Latosol (Embrapa 2018). Soil, samples were taken for physical and chemical analysis of the soil at the Brazilian Institute of Analysis (IBRA), according to the methodology described by (Silva 1999). The soil analysis demonstrated the need to correct only the potassium content with the application of $60 \mathrm{~kg} \mathrm{ha}^{-1}$ of potassium chloride (Table 1), following the recommendation of De Oliveira et al (2018). Climatic data from the experimental area were collected during the conduct of the experiment (Fig. 1).

\section{Experimental design}

The experimental design adopted was a completely randomized block, in a $4 \times 2 \times 2$ factorial scheme, composed of four doses of $\mathrm{N}\left(0 ; 60 ; 120\right.$ and $180 \mathrm{~kg} \mathrm{ha}^{-1}$ of $\mathrm{N})$ following the recommendation of (Ritchie et al. 1993), two sources of $\mathrm{N}$, common urea (with $45 \% \mathrm{~N}$ ) and urease inhibitor-treated urea - NBPT (with $45 \% \mathrm{~N}$ ) and presence and absence of $A$. brasilense, with four replications.

\section{Source and sowing of seeds}

The seed used in the experiment was the K9960 VIP3 Zea mays hybrid (classified as high productive potential, excellent stem health, high planting adaptability for tropical/ subtropical regions and early cycle), commonly adopted in the southeastern region of the state of Pará. It was donated by the company Juparanã. Early after collection, the soil was sieved in a $2-\mathrm{mm}$ sieve, then homogenized in $256 \mathrm{~kg}$ of organic material from mango pruning residues for $768 \mathrm{~kg}$ of soil. The $25 \times 32 \mathrm{~cm}\left(490.8 \mathrm{~cm}^{2}\right)$ pots were filled with $16 \mathrm{~kg}$ of substrate, prepared by mixing the soil with organic matter in a 3:1 ratio, respectively.

\section{Treatment application}

For the treatments inoculation purpose, the seeds were homogenized together with the inoculant $(200 \mathrm{~mL}$ diluted in water equivalent to $10 \%$ of the weight of the seeds, strains $\mathrm{Ab}-\mathrm{V} 5$ and Ab-V6 in the concentration $2 \times 10^{8} \mathrm{CFU} \mathrm{mL}^{-1}$ ), inoculated one hour before sowing (Leite et al. 2019). N doses with common urea and urea inhibitor were applied in topdressing once, performed at $10 \mathrm{DAE}$ (days after plant emergence) when the plant started to develop its secondary root system following the recommendation of (Jadoski et al. 2016). The buckets received controlled daily irrigation to replace the water lost through evapotranspiration over the experimental period, and the soil water content was maintained closer to the field capacity, using the gravimetric method (Catuchi et al. 2011), which consists of replacing the irrigation depth based on daily weighing of the buckets. The control of weeds and pests was carried out daily and manually through mechanical plucking and manual picking, respectively. 


\section{Plant phenology and measurement}

The evaluations were carried out on the full male flowering $\left(\mathrm{V}_{\mathrm{T}}\right.$ phenological stage), that is, at plant tasseling (Ritchie et al. 1993). At 50 days after germination, (period that stabilized the growth of the aerial part), the variables of vegetative growth and gas exchange were measured.

The measurements related to plant height $(\mathrm{PH})$ and stem diameter (SD), were performed with the aid of a ruler and digital caliper, respectively; then, the plants were sectioned into different parts (leaves, root, stem + sheath), packed in 5-kg paper bags, identified and taken to the forced air circulation oven at $65 \pm 2^{\circ} \mathrm{C}$ for $72 \mathrm{~h}$. Upon reaching constant weight, each part of the plant was weighed on an analytical scale to determine the dry mass of the root (RDM), dry mass of the leaf (LDM), dry mass of the stem (SDM), dry mass of the aerial part (APDM) (calculated as the sum of the dry mass of stem and leaf) and total dry mass (TDM). The number of leaves (LN) was obtained through manual counting, considering all the completely expanded leaves. For determination of the leaf area (LA), length (L) and width $(\mathrm{W})$ were measured in the median part of all leaves of each of the plants, to obtain the initial LA according to (Sangoi et al. 2007). Using the proposal of Sangoi et al. (2007) the calculation of the leaf area was obtained using the following equation: LA $\left(\mathrm{m}^{2}\right)=0.75 \times$ Width $\times$ length of the leaf. Afterwards, the individual values of all the leaves were summed to obtain the value of total leaf area per plant.

\section{Gas Exchange evaluation}

Gas exchanges were determined on the second leaf, from the base (lower), and on the first fully mature leaf, from the apex (upper), on a day with clear sky (no clouds), representing the daytime period in which photosynthesis reaches maximum values, according to what was determined from the daytime curves of leaf exchanges, that is, between $08 \mathrm{~h}$ at $11 \mathrm{~h}$. The net assimilation rate of $\mathrm{CO}_{2}$ $(A)$, stomatal conductance to water vapor $(g s)$, intercellular $\mathrm{CO}_{2}$ concentration $(\mathrm{Ci})$ and leaf transpiration rate $(E)$, were measured in the range from $08 \mathrm{~h}$ to $10 \mathrm{~h} 30 \mathrm{~min}$ in the maximum photosynthesis of the daytime curve, using a portable gas exchange model open flow system (LI-640002B, LI-COR Inc., Lincoln, NE, USA), under an external $\mathrm{CO}_{2}$ concentration of $400 \mu \mathrm{mol} \mathrm{mol}{ }^{-1}$ of air and under a flow of photosynthetically active radiation of $900 \mu \mathrm{mol} \mathrm{m}$ $\mathrm{s}^{-1}$ of photons. Subsequently, the internal and external carbon $(\mathrm{Ci} / \mathrm{Ca})$ ratio was calculated.

\section{Photosynthetic pigment determination}

First, $100 \mathrm{mg}$ of fresh leaf from each sample was weighed, then, placed in a mortar, containing $3 \mathrm{~mL}$ of $80 \%$ acetone, followed by maceration and filtering with paper towels. The supernatant was transferred to a volumetric flask, measuring
Table 1: Physico-chemical soil characteristics at 0-20 cm depth. The soil was sampled prior to corn sowing

\begin{tabular}{|c|c|c|}
\hline Characteristics & Values & Unit \\
\hline Total N & 4.96 & $\mathrm{Mg} \mathrm{ha}^{-1}$ \\
\hline $\mathrm{pH}$ & 5.40 & - \\
\hline Organic matter & 36.00 & $\mathrm{~g} \mathrm{dm}^{-3}$ \\
\hline Organic carbon & 21.00 & $\mathrm{~g} \mathrm{dm}^{-3}$ \\
\hline Phosphate-P & 0.13 & $\mathrm{~g} \mathrm{dm}^{-3}$ \\
\hline $\mathrm{K}^{+}$ & 1.50 & $\mathrm{mmol}_{\mathrm{c}} \mathrm{dm}^{-3}$ \\
\hline $\mathrm{Ca}^{2+}$ & 48.00 & $\mathrm{mmol}_{\mathrm{c}} \mathrm{dm}^{-3}$ \\
\hline $\mathrm{Mg}^{2+}$ & 11.00 & $\mathrm{mmol}_{\mathrm{c}} \mathrm{dm}^{-3}$ \\
\hline $\mathrm{H}+\mathrm{Al}$ & 29.00 & $\mathrm{mmol}_{\mathrm{c}} \mathrm{dm}^{-3}$ \\
\hline Sulfur + Boron & 124.00 & $\mathrm{mmol}_{\mathrm{c}} \mathrm{dm}^{-3}$ \\
\hline Cation exchange capacity & 153.00 & $\mathrm{mmol}_{\mathrm{c}} \mathrm{dm}^{-3}$ \\
\hline Saturation of bases & 68.00 & $\%$ \\
\hline $\mathrm{Cu}^{2+}$ & 1.60 & $\mathrm{mg} \mathrm{dm}^{-3}$ \\
\hline $\mathrm{Fe}^{3+}$ & 37.00 & $\mathrm{mg} \mathrm{dm}^{-3}$ \\
\hline $\mathrm{Mn}^{2+}$ & 36.30 & $\mathrm{mg} \mathrm{dm}^{-3}$ \\
\hline $\mathrm{Zn}^{2+}$ & 52.00 & $\mathrm{mg} \mathrm{dm}^{-3}$ \\
\hline Boron & 0.59 & $\mathrm{mg} \mathrm{dm}^{-3}$ \\
\hline Sulfur & 16.00 & $\mathrm{mg} \mathrm{dm}^{-3}$ \\
\hline Silt & 99.00 & $\mathrm{~g} \mathrm{~kg}^{-1}$ \\
\hline Clay & 136.00 & $\mathrm{~g} \mathrm{~kg}^{-1}$ \\
\hline Sand & 765.00 & $\mathrm{~g} \mathrm{~kg}^{-1}$ \\
\hline
\end{tabular}

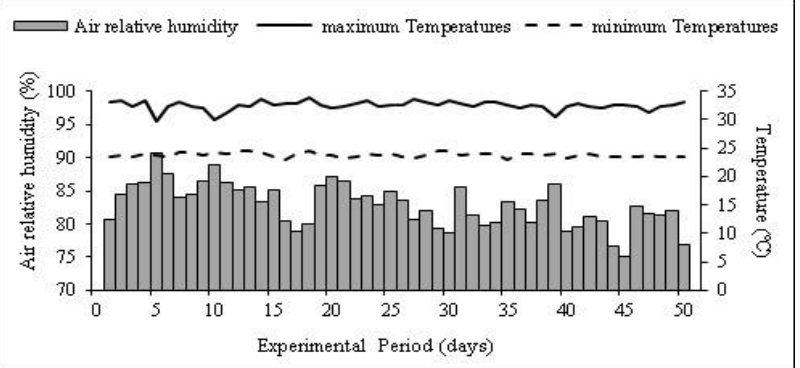

Fig. 1: Air relative humidity and maximum and minimum temperatures of the experimental area over the experimental period in 2019, in Belém, Pará, Brazil

the volume to $25 \mathrm{~mL}$. After, the samples were read on a spectrophotometer at $663 \mathrm{~nm}(\mathrm{Chl} \mathrm{a}), 647 \mathrm{~nm}(\mathrm{Chl} \mathrm{b})$ and $470 \mathrm{~nm}$ (carotenoids) and as white, only $80 \%$ acetone was used, with final concentrations of chlorophylls and carotenoids calculated according to the methodology recommended by Sims and Gamon (2002).

\section{Statistical analysis}

The results of the analysis of growth and gas exchange were submitted to the tests of Shapiro-Wilks and Levene to verify the normality and homoscedasticity of the data, respectively. After meeting the basic assumptions, the analysis of variance was carried out, in which the unfolding was carried out, proving to be significant To assess the effect of different doses of $\mathrm{N}$, fertilizers and inoculation on corn hybrid, analysis of variance was performed, with Tukey test at $5 \%$ probability, and adjusted for polynomial regression to differentiate whether there was a linear or nonlinear response to the $\mathrm{N}$ rates applied, using the Sisvar statistical software program (Ferreira 2019). 
Palheta et al. / Intl J Agric Biol, Vol 26, No 2, 2021

Table 2: Summary of analysis of variance, applied on growth characteristics of corn in accordance with the source (S), A. brasilense inoculation (I), and nitrogen doses (D)

\begin{tabular}{|c|c|c|c|c|c|c|c|c|c|c|}
\hline \multirow[t]{2}{*}{ Cause of variation } & \multirow[t]{2}{*}{$\mathrm{DF}$} & \multicolumn{9}{|c|}{ Mean squares } \\
\hline & & SD & $\mathrm{PH}$ & LA & $\mathrm{LN}$ & LDM & APDM & TDM & SDM & RDM \\
\hline Source (S) & 1 & $0.070^{\mathrm{ns}}$ & $0.023^{\mathrm{ns}}$ & $0.001^{\mathrm{ns}}$ & $0.350^{\mathrm{ns}}$ & $0.003^{\mathrm{ns}}$ & $0.001^{\mathrm{ns}}$ & $0.001^{\mathrm{ns}}$ & $0.003^{\mathrm{ns}}$ & $0.030^{\mathrm{ns}}$ \\
\hline Inoculation (I) & 1 & $0.665^{\mathrm{ns}}$ & $0.023^{\mathrm{ns}}$ & $0.001^{\mathrm{ns}}$ & $0.450^{\mathrm{ns}}$ & $0.009^{\mathrm{ns}}$ & $0.001^{\mathrm{ns}}$ & $0.001^{\mathrm{ns}}$ & $0.001^{\mathrm{ns}}$ & $0.009^{\mathrm{ns}}$ \\
\hline $\mathrm{S} \times \mathrm{I}$ & 1 & $0.006^{\mathrm{ns}}$ & $0.002^{\mathrm{ns}}$ & $0.001^{\mathrm{ns}}$ & $0.056^{\mathrm{ns}}$ & $0.001^{\mathrm{ns}}$ & $0.001^{\mathrm{ns}}$ & $0.001^{\mathrm{ns}}$ & $0.001^{\mathrm{ns}}$ & $0.005^{\mathrm{ns}}$ \\
\hline $\mathrm{S} \times \mathrm{D}$ & 3 & $0.255^{\mathrm{ns}}$ & $0.014^{\mathrm{ns}}$ & $0.001^{\mathrm{ns}}$ & $1.163^{\mathrm{ns}}$ & $0.002^{\mathrm{ns}}$ & $0.001^{\mathrm{ns}}$ & $0.001^{\mathrm{ns}}$ & $0.010^{\mathrm{ns}}$ & $0.005^{\mathrm{ns}}$ \\
\hline $\mathrm{I} \times \mathrm{D}$ & 3 & $0.274^{\mathrm{ns}}$ & $0.027^{\mathrm{ns}}$ & $0.001^{\mathrm{ns}}$ & $4.916^{*}$ & $0.017^{*}$ & $0.004^{*}$ & $0.003^{*}$ & $0.028^{\mathrm{ns}}$ & $0.022^{\mathrm{ns}}$ \\
\hline $\mathrm{S} \times \mathrm{I} \times \mathrm{D}$ & 3 & $0.605^{*}$ & $0.016^{\mathrm{ns}}$ & $0.001^{\mathrm{ns}}$ & $2.326^{\mathrm{ns}}$ & $0.007^{\mathrm{ns}}$ & $0.002^{\mathrm{ns}}$ & $0.001^{\mathrm{ns}}$ & $0.013^{\mathrm{ns}}$ & $0.009^{\mathrm{ns}}$ \\
\hline Blocks & 3 & $0.504^{*}$ & $0.017^{\mathrm{ns}}$ & $0.001^{\mathrm{ns}}$ & $1.098^{\mathrm{ns}}$ & $0.009^{\mathrm{ns}}$ & $0.003^{\mathrm{ns}}$ & $0.002^{\mathrm{ns}}$ & $0.042^{*}$ & $0.008^{\mathrm{ns}}$ \\
\hline Residue & 45 & 0.175 & 0.014 & 0.001 & 1.822 & 0.003 & 0.001 & 0.001 & 0.014 & 0.009 \\
\hline $\mathrm{CV}(\%)$ & - & 5.0 & 2.5 & 0.5 & 1.7 & 3.0 & 1.8 & 1.5 & 4.7 & 5.7 \\
\hline
\end{tabular}

ns: not significant, *: significant at $5 \%$ probability by the $\mathrm{F}$ test, $\mathrm{CV}$ : coefficient of variation

Table 3: Summary of analysis of variance for gas exchange and pigments contents of corn leaves in accordance with the source (S), the inoculation of $A$. brasilense (I), and the nitrogen doses (D)

\begin{tabular}{|c|c|c|c|c|c|c|c|c|c|c|}
\hline \multirow[t]{2}{*}{ Cause of variation } & \multirow[t]{2}{*}{$\mathrm{DF}$} & \multicolumn{9}{|c|}{ Mean squares } \\
\hline & & $A$ & $C i$ & $g s$ & $E$ & $\mathrm{Ci} / \mathrm{Ca}$ & Chl a & Chl b & Chl total & Carotenoids \\
\hline$\overline{\text { Source }(\mathrm{S})}$ & 1 & $0.003^{\mathrm{ns}}$ & $4544.4^{\mathrm{ns}}$ & $0.47^{\mathrm{ns}}$ & $0.081^{\mathrm{ns}}$ & $0.003^{*}$ & $17819.00^{*}$ & $6728.60^{*}$ & $29.69^{*}$ & $663.94^{\mathrm{ns}}$ \\
\hline Inoculation (I) & 1 & $0.202^{*}$ & $402.84^{\mathrm{ns}}$ & $10.72^{*}$ & $6.93^{*}$ & $0.001^{\mathrm{ns}}$ & $610.19^{\mathrm{ns}}$ & $14.32^{\mathrm{ns}}$ & $2.06^{\mathrm{ns}}$ & $1012.90^{\mathrm{ns}}$ \\
\hline $\mathrm{S} \times \mathrm{I}$ & 1 & $0.006^{\mathrm{ns}}$ & $6807.1^{\mathrm{ns}}$ & $0.57^{\mathrm{ns}}$ & $7.37^{*}$ & $0.001^{\mathrm{ns}}$ & $17251.00^{*}$ & $11682.00^{*}$ & $1.04^{\mathrm{ns}}$ & $420.51^{\mathrm{ns}}$ \\
\hline $\mathrm{S} \times \mathrm{D}$ & 3 & $0.022^{\mathrm{ns}}$ & $385.01^{\mathrm{ns}}$ & $2.05^{\mathrm{ns}}$ & $6.65^{*}$ & $0.001^{\mathrm{ns}}$ & $9539.200^{*}$ & $7078.90^{*}$ & $30.91^{*}$ & $10985.00^{*}$ \\
\hline $\mathrm{I} \times \mathrm{D}$ & 3 & $0.020^{\mathrm{ns}}$ & $1222.6^{\mathrm{ns}}$ & $1.47^{\mathrm{ns}}$ & $0.31^{\mathrm{ns}}$ & $0.001^{\mathrm{ns}}$ & $2240.400^{\mathrm{ns}}$ & $3701.400^{*}$ & $10.69^{\mathrm{ns}}$ & $2331.500^{*}$ \\
\hline $\mathrm{S} \times \mathrm{I} \times \mathrm{D}$ & 3 & $0.015^{\mathrm{ns}}$ & $3107.5^{\mathrm{ns}}$ & $0.68^{\mathrm{ns}}$ & $0.83^{\text {ns }}$ & $0.001^{\mathrm{ns}}$ & $8301.100^{\mathrm{ns}}$ & $3161.500^{*}$ & $22.03^{*}$ & $462.01^{\mathrm{ns}}$ \\
\hline Blocks & 3 & $0.101^{*}$ & $74001.0^{*}$ & $3.56^{\mathrm{ns}}$ & $14.47^{*}$ & $0.006^{*}$ & $1666.400^{\mathrm{ns}}$ & $590.57^{\mathrm{ns}}$ & $11.52^{\mathrm{ns}}$ & $322.18^{\mathrm{ns}}$ \\
\hline Residue & 45 & 0.024 & 3313.1 & 2.24 & 1.60 & 0.001 & 2973.4 & 1013.8 & 7.01 & 621.89 \\
\hline $\mathrm{CV}(\%)$ & - & 5.5 & 20.9 & 18.8 & 8.9 & 6.9 & 2.2 & 1.2 & 1.9 & 1.0 \\
\hline
\end{tabular}

ns: not significant, *: significant at $5 \%$ probability by the $\mathrm{F}$ test, $\mathrm{CV}$ : coefficient of variation

\section{Results}

The results of the analysis of variance (Tables 2 and 3) showed a significant effect by means of the $\mathrm{F}$ test $(\mathrm{P}<0.05)$ of $\mathrm{N}$ sources, inoculation with $A$. brasilense and $\mathrm{N}$ doses in the growth and the evaluated physiological parameters, except the internal concentration of carbon. The significant effect on the triple interaction (Source $\times$ Inoculation $\times$ Doses) was observed for stem diameter, Chl b and total Chl, indicating the dependence on the factors evaluated in the experiment.

\section{Plant growth and biomass yield}

A significant effect was found for the SD in the triple interaction (Source $\times$ Inoculation $\times$ Dose) $($ Table 2 ). The SD in the corn plants with application of urea without inoculation resulted in a quadratic behavior for the $\mathrm{N}$ doses, with the highest value of $17.22 \mathrm{~mm}$ obtained in the dose of $149.75 \mathrm{~kg} \mathrm{ha}^{-1} \mathrm{~N}$, while the urea with $A$. brasilense and urease-inhibitor in the absence and presence of the bacteria treatments obtained adjustment for the increasing linear equation, in which the maximum dose of $180 \mathrm{~kg} \mathrm{ha}^{-1} \mathrm{~N}$ promoted the maximum values of $17.26,17.05$ and 17.44 $\mathrm{mm}$ in diameter, respectively. The inoculation of corn with the bacteria promoted a higher increase in stem diameter than that found in plants without inoculation (Table 4).

The plant height (AP) and leaf area (AF) had a significant effect on the Dose factor, with the best fit for the quadratic equation (Table 2). The increase in $\mathrm{N}$ doses positively influenced the phytotechnical values of the crop. It was observed in this study that the doses of 152.11 and $157.75 \mathrm{~kg} \mathrm{ha}^{-1} \mathrm{~N}$ were those that provided the highest $\mathrm{PH}$ $(122.50 \mathrm{~cm})$ and LA $\left(43.61 \mathrm{dm}^{2}\right)$, respectively (Table 5). For the variable number of leaves (NL), it was observed a significant effect on the Inoculation $\times$ Doses interaction, adjusting to the quadratic regression model (Table 2). From the information in (Table 6), it was found that the number of leaves for plants without inoculation reached a maximum value of 14.22 plant $^{-1}$ in the estimated dose of $180 \mathrm{~kg} \mathrm{ha}^{-1} \mathrm{~N}$, while for the inoculated plants, the number of leaves reached a value of 13.72 plant $^{-1}$ at the dose of $131.25 \mathrm{~kg} \mathrm{ha}^{-1}$ N.

The attributes including LDM, APDM and TDM were significant for the Inoculation $\times$ Dose interaction (Table 2). The treatments with urea in the absence and presence of $A$. brasilense resulted in the best fit to the quadratic regression model, in which the LDM variable obtained a value of $27.03 \mathrm{~g} \mathrm{plant}^{-1}$ at a dose of $182.37 \mathrm{~kg} \mathrm{ha}^{-1} \mathrm{~N}$ and $25.57 \mathrm{~g}$ plant $^{-1}$ at a dose of $148.37 \mathrm{~kg} \mathrm{ha}^{-1}$ of $\mathrm{N}$, respectively (Table $6)$.

For the APDM, maximum values of 73.56 and $68.89 \mathrm{~g}$ plant $^{-1}$ were found at doses of 177.73 and $158.41 \mathrm{~kg} \mathrm{ha}^{-1}$ of $\mathrm{N}$ with the source urea in the absence and presence of Azospirillum, respectively. While, the highest TDM values of 89.08 and $83.12 \mathrm{~g} \mathrm{plant}^{-1}$ were obtained at doses of 
Table 4: Unfolding of the Source $\times$ Inoculation $\times$ Dose interaction with regression equation and estimate of maximum technical efficiency, applied to the content of chlorophyll $b$ and total chlorophyll, and SD in corn hybrid without and with inoculation with $A$. brasilense

\begin{tabular}{|c|c|c|c|c|c|c|c|c|c|}
\hline \multirow[t]{2}{*}{ Variable } & \multirow[t]{2}{*}{ N source } & \multicolumn{4}{|c|}{$\mathrm{N}$ dose $\left(\mathrm{kg} \mathrm{ha}^{-1}\right)$} & \multirow[t]{2}{*}{ Equation } & \multirow[t]{2}{*}{$\mathrm{R}^{2}$} & \multirow[t]{2}{*}{ Ymet } & \multirow[t]{2}{*}{ Nmet } \\
\hline & & 0 & 60 & 120 & 180 & & & & \\
\hline Chl b & Urea without & 0.0014 & 0.0013 & 0.0018 & 0.0006 & $Y=-0.00000008 x^{2}+0.00001 x+0.0013$ & 0.60 & 0.0016 & 65.16 \\
\hline \multirow[t]{2}{*}{$\left(\mathrm{mmol} \mathrm{kg}{ }^{-1} \mathrm{MF}\right)$} & Urea with & 0.0014 & 0.0007 & 0.0006 & 0.0009 & $y=0.00000007 x^{2}-0.00001 x+0.0013$ & 0.99 & 0.0009 & 71.42 \\
\hline & Inhibitor with & 0.0009 & 0.0021 & 0.0019 & 0.0012 & $y=-0.0000001 x^{2}+0.00002 x+0.001$ & 0.97 & 0.002 & 100.00 \\
\hline & Urea without & 0.0026 & 0.0030 & 0.0042 & 0.0023 & $y=-0.0000002 x^{2}+0.00003 x+0.0025$ & 0.63 & 0.0036 & 75.00 \\
\hline \multirow[t]{3}{*}{$\left(\mathrm{mmol} \mathrm{kg}{ }^{-1} \mathrm{MF}\right)$} & Urea with & 0.0038 & 0.0027 & 0.0025 & 0.0040 & $y=0.0000002 x^{2}-0.00003 x+0.0038$ & 0.97 & 0.0026 & 75.00 \\
\hline & Inhibitor without & 0.0025 & 0.0046 & 0.0040 & 0.0035 & $y=-0.0000002 x^{2}+0.00004 x+0.0026$ & 0.82 & 0.0046 & 100.00 \\
\hline & Inhibitor with & 0.0024 & 0.0048 & 0.0043 & 0.0032 & $y=-0.0000002 x^{2}+0.00005 x+0.0025$ & 0.92 & 0.0056 & 125.00 \\
\hline SD & Urea without & 128.65 & 152.32 & 173.97 & 168.60 & $y=-0.0002 x^{2}+0.0599 x+12.74$ & 0.97 & 17.22 & 149.75 \\
\hline \multirow[t]{3}{*}{$(\mathrm{mm})$} & Urea with & 142.75 & 158.77 & 169.47 & 172.67 & $y=0.0167 x+14.585$ & 0.92 & - & - \\
\hline & Inhibitor without & 137.30 & 167.97 & 155.25 & 170.57 & $y=0.0145 x+14.471$ & 0.54 & - & - \\
\hline & Inhibitor with & 144.45 & 155.07 & 174.55 & 174.47 & $y=0.0183 x+14.571$ & 0.89 & - & - \\
\hline
\end{tabular}

Table 5: Unfolding of the nitrogen dose effect, with regression equation and estimate of the maximum technical efficiency, (some growth attributes) in corn hybrid submitted to nitrogen doses

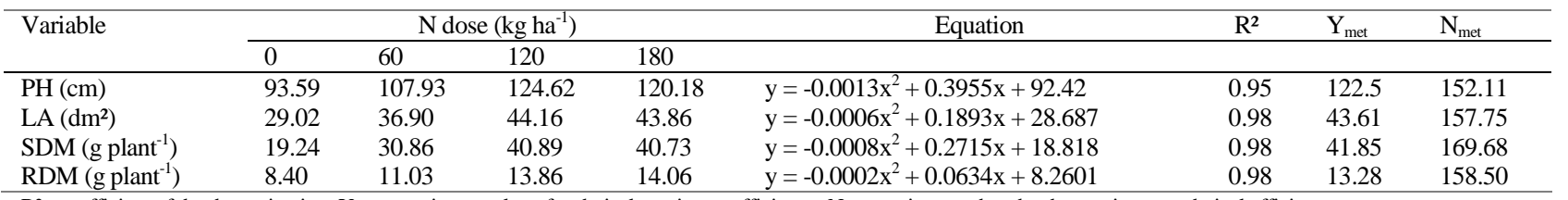

$\mathrm{R}^{2}$ - coefficient of the determination; Ymet - estimate value of technical maximum efficiency; Nmet - nitrogen dose by the maximum technical efficienc

186.89 and $159.28 \mathrm{~kg} \mathrm{ha}^{-1}$ of $\mathrm{N}$ with the application of urea in the absence and presence of the bacteria, respectively (Table 6). The SDM and RDM variables had a significant effect on the dose factor, with the best adjustment of the data to the quadratic equation, in which the doses of 169.68 and $158.50 \mathrm{~kg} \mathrm{ha}^{-1} \mathrm{~N}$ provided the highest values of 41.85 and $13.28 \mathrm{~g} \mathrm{plant}^{-1}$, respectively (Table 5).

\section{Gas exchange characteristics}

The analysis of variance identified a significant effect ( $p$ $<0.05$ ) of the isolated factors Inoculation and Dose for the net assimilation rate of photosynthesis (A), with adjustment to the increasing linear regression model (Table 3). The application of $\mathrm{N}$ in topdressing in the absence of the bacteria promoted values that varied from 13.07 to $18.23 \mu \mathrm{mol} \mathrm{m}^{-2} \mathrm{~s}$ 1 , whereas in corn inoculated with $A$. brasilense the values ranged from 16.00 to $19.85 \mu \mathrm{mol} \mathrm{m}^{-2} \mathrm{~s}^{-1}$ at doses zero to 180 $\mathrm{kg} \mathrm{ha}^{-1}$ of N, respectively (Table 6), verifying that the plants in the presence of Azospirillum showed greater photosynthetic activity.

gs: This attribute had a significant effect on the isolated factors Inoculation and Dose (Table 3), adjusting to the linear regression model, in which the increase in the doses promoted an improvement in conductance, ranging from 0.126 to $0.156 \mu \mathrm{mol} \mathrm{m} \mathrm{m}^{-2} \mathrm{~s}^{-1}$ in corn plants with no inoculation and 0.142 to $0.158 \mu \mathrm{mol} \mathrm{m}^{-2} \mathrm{~s}^{-1}$ in plants with the presence of Azospirillum at the dose of 0 and $180 \mathrm{~kg} \mathrm{ha}^{-1}$ $\mathrm{N}$, respectively (Table 6).

$\boldsymbol{E}$ : The experimental data on $E$ were submitted to analysis of variance, where an effect was observed on the Source $x$
Inoculation and Source $\times$ Dose interactions (Table 3). Through the unfolding of the Source $x$ Inoculation interaction, it was verified that the urea with inoculation presented a mean of $3.48 \mathrm{mmol} \mathrm{m}^{-2} \mathrm{~s}^{-1}$, followed by the urease-inhibitor in the absence $\left(3.27 \mathrm{mmol} \mathrm{m}^{-2} \mathrm{~s}^{-1}\right)$ and presence $\left(3.23 \mathrm{mmol} \mathrm{m}^{-2} \mathrm{~s}^{-1}\right)$ of the bacteria Azospirillum, while urea without inoculation resulted in a value of 2.85 mmol $\mathrm{m}^{-2} \mathrm{~s}^{-1}$ of $E$ (Table 7). For the Source $\times$ Dose interaction, the results did not fit any mathematical model, with a mean of 2.97 and $3.20 \mathrm{mmol} \mathrm{m}^{-2} \mathrm{~s}^{-1}$ for corn plant with urea and 3.09 and $3.62 \mathrm{mmol} \mathrm{m}^{-2} \mathrm{~s}^{-1}$ with urea inhibitor at a dose of 0 and $180 \mathrm{~kg} \mathrm{ha}^{-1} \mathrm{~N}$, respectively (Table 8).

Internal and external carbon $(\mathrm{Ci} / \mathrm{Ca})$ ratio: In the internal and external carbon $(\mathrm{Ci} / \mathrm{Ca})$ ratio, the analysis of variance had a significant effect on the isolated factors Source and $\mathrm{N}$ Dose (Table 3). When fertilized with urea, it was found that the results did not fit any mathematical model, showing a mean of $0.471 \mu \mathrm{mol} \mathrm{mol}^{-1}$, while for the urea inhibitor, there was a quadratic effect, where the lowest value for this characteristic was $0.47 \mu \mathrm{mol} \mathrm{mol}^{-1}$ at an estimated dose of $85.71 \mathrm{~kg} \mathrm{ha}^{-1} \mathrm{~N}$, followed by a growth up to the maximum dose (Table 8).

\section{Photosynthetic pigments}

According to the analysis of variance for the content of Chl a, we found significant Source $\times$ Inoculation and Source $\times$ Dose interactions (Table 3). The Source $x$ Inoculation interaction showed that the urea treatments with Azospirillum and urease-inhibitor in the absence and presence of the bacterium were statistically similar, differing 
Table 6: Unfolding of the analysis of variance with regression equation and estimation of maximum growth attributes, gas exchange and carotenoids in corn hybrid grown in the absence and presence of $A$. brasilense and the nitrogen dose

\begin{tabular}{|c|c|c|c|c|c|c|c|c|c|}
\hline \multirow[t]{2}{*}{ Variable } & \multirow[t]{2}{*}{ Azospirillum } & \multicolumn{4}{|c|}{ Dose $\left(\mathrm{kg} \mathrm{ha}^{-1}\right)$} & \multirow[t]{2}{*}{ Equation } & \multirow[t]{2}{*}{$\mathrm{R}^{2}$} & \multirow[t]{2}{*}{ Ymet } & \multirow[t]{2}{*}{ Nmet } \\
\hline & & $\overline{0}$ & 60 & 120 & 180 & & & & \\
\hline \multirow[t]{2}{*}{$\overline{\mathrm{LN}}$} & Absence & 11.75 & 13.50 & 13.25 & 14.25 & $y=-0.00005 x^{2}+0.0215 x+11.913$ & 0.83 & 14.22 & 180.00 \\
\hline & Presence & 12.42 & 13.14 & 14.00 & 13.62 & $y=-0.00008 x^{2}+0.021 x+12.36$ & 0.93 & 13.73 & 131.25 \\
\hline \multirow[t]{2}{*}{ LDM $\left(\mathrm{g}\right.$ plant $\left.{ }^{-1}\right)$} & Absence & 13.35 & 22.26 & 24.69 & 28.20 & $y=-0.0004 x^{2}+0.1459 x+13.729$ & 0.97 & 27.03 & 182.37 \\
\hline & Presence & 17.35 & 20.81 & 27.52 & 25.73 & $y=-0.0004 x^{2}+0.1187 x+16.764$ & 0.89 & 25.57 & 148.37 \\
\hline \multirow[t]{2}{*}{$\operatorname{APDM}\left(\mathrm{g}_{\text {plant }}{ }^{-1}\right)$} & Absence & 31.79 & 57.78 & 67.55 & 75.27 & $y=-0.0013 x^{2}+0.4621 x+32.499$ & 0.99 & 73.56 & 177.73 \\
\hline & Presence & 40.63 & 51.73 & 72.77 & 66.68 & $y=-0.0012 x^{2}+0.3802 x+38.78$ & 0.89 & 68.89 & 158.41 \\
\hline \multirow[t]{2}{*}{ TDM (g plant $\left.{ }^{-1}\right)$} & Absence & 39.28 & 69.26 & 80.21 & 90.14 & $y=-0.0014 x^{2}+0.5233 x+40.181$ & 0.98 & 89.08 & 186.89 \\
\hline & Presence & 49.93 & 62.32 & 87.83 & 79.95 & $y=-0.0014 x^{2}+0.446 x+47.606$ & 0.87 & 83.12 & 159.28 \\
\hline \multirow[t]{2}{*}{$A\left(\mu \mathrm{mol} . \mathrm{m}^{-2} . \mathrm{s}^{-1}\right)$} & Absence & 13.07 & 16.44 & 17.43 & 18.23 & $y=0.0274 x+13.829$ & 0.87 & - & - \\
\hline & Presence & 16.00 & 17.18 & 20.20 & 19.85 & $y=0.0243 x+16.125$ & 0.84 & - & - \\
\hline \multirow[t]{2}{*}{$g s\left(\mu \mathrm{mol} . \mathrm{m}^{-2} \cdot \mathrm{s}^{-1}\right)$} & Absence & 0.12 & 0.133 & 0.150 & 0.156 & $y=0.0002 x+0.1251$ & 0.95 & - & - \\
\hline & Presence & 0.14 & 0.140 & 0.177 & 0.158 & $y=0.1543$ & - & - & - \\
\hline \multirow{2}{*}{$\begin{array}{l}\text { Carotenoids } \\
\left(\mathrm{mmol} \mathrm{kg}^{-1} \mathrm{MF}\right)\end{array}$} & Absence & 0.001 & 0.002 & 0.001 & 0.001 & $y=-0.00000007 x^{2}+9 E-06 x+0.0013$ & 0.99 & 0.001 & 64.28 \\
\hline & Presence & 0.002 & 0.001 & 0.001 & 0.001 & $y=-0.000005 x+0.0017$ & 0.98 & - & - \\
\hline
\end{tabular}

Table 7: Summary of the mean analysis of the Source $\times$ Inoculation interaction, in accordance with the absence and presence of $A$. brasilense in corn seed, in transpiration $\left(\mathrm{mmol} \mathrm{m}^{-2} \mathrm{~s}^{-1}\right)$ and chlorophyll $a$ concentration $\left(\mathrm{mmol} \mathrm{kg} \mathrm{MF}^{-1}\right)$

\begin{tabular}{llll}
\hline N source & Azospirillum & Transpiration & Chlorophyll $a$ \\
\hline Urea & Absence & $2.85 \pm 0.55 \mathrm{Ab}$ & $0.0016 \pm 0.0008 \mathrm{Ba}$ \\
& Presence & $3.48 \pm 0.57 \mathrm{Aa}$ & $0.0021 \pm 0.0006 \mathrm{Aa}$ \\
Inhibitor & Absence & $3.27 \pm 0.70 \mathrm{Aa}$ & $0.0025 \pm 0.0011 \mathrm{Aa}$ \\
& Presence & $3.23 \pm 0.66 \mathrm{Aa}$ & $0.0021 \pm 0.0007 \mathrm{Aa}$ \\
\hline
\end{tabular}

Columns with different capital letters between $\mathrm{N}$ source treatments (urea and inhibitor under the same inoculation treatment) and lower case letters between inoculation treatments (absence and presence of Azospirilum under the same $\mathrm{N}$ source) indicate significant differences by the Tukey test (P<0.05). Values described correspond to the average of 4 repetitions and Standard Deviation

Table 8: Unfolding of the Source $\times$ Dose interaction, with regression equation and estimate of the maximum technical efficiency, applied to the transpiration $(E)$, internal and external carbon ratio $(\mathrm{Ci} / \mathrm{Ca})$, chlorophyll $a(\mathrm{Chl} a)$ and carotenoids, in hybrid seed of corn subjected to different sources of nitrogen

\begin{tabular}{|c|c|c|c|c|c|c|c|c|c|}
\hline \multirow[t]{2}{*}{ Variable } & \multirow[t]{2}{*}{$\mathrm{N}$ source } & \multicolumn{4}{|c|}{ Dose $\left(\mathrm{kg} \mathrm{ha}^{-1}\right)$} & \multirow[t]{2}{*}{ Equation } & \multirow[t]{2}{*}{$\mathrm{R}^{2}$} & \multirow[t]{2}{*}{ Ymet } & \multirow[t]{2}{*}{ Nmet } \\
\hline & & $\overline{0}$ & 60 & 120 & 180 & & & & \\
\hline \multirow{2}{*}{$E\left(\mathrm{mmol} \mathrm{m}^{-2} \mathrm{~s}^{-1}\right)$} & Urea & 2.97 & 3.48 & 3.003 & 3.20 & $y=3.1666$ & - & - & - \\
\hline & Inhibitor & 3.09 & 2.84 & 3.36 & 3.62 & $\mathrm{y}=3.2337$ & - & - & - \\
\hline \multirow[t]{2}{*}{$\mathrm{Ci} / \mathrm{Ca}$} & Urea & 0.47 & 0.44 & 0.48 & 0.488 & $y=0.4724$ & - & - & - \\
\hline & Inhibitor & 0.54 & 0.42 & 0.54 & 0.53 & $y=0.000007 x^{2}-0.0012 x+0.5225$ & 0.36 & 0.47 & 85.71 \\
\hline \multirow[t]{2}{*}{$\left.\mathrm{Chl} \mathrm{a} \mathrm{(mmol} \mathrm{kg}{ }^{-1} \mathrm{MF}\right)$} & Urea & 0.002 & 0.002 & 0.002 & 0.002 & $y=0.0019$ & - & - & - \\
\hline & Inhibitor & 0.002 & 0.003 & 0.002 & 0.002 & $y=-0.00000008 x^{2}+0.00002 x+0.0018$ & 0.43 & 0.003 & 125 \\
\hline \multirow[t]{2}{*}{ Carotenoids (mmol kg ${ }^{-1} \mathrm{MF}$ ) } & Urea & 0.001 & 0.002 & 0.002 & 0.000 & $y=-0.0000001 x^{2}+0.00001 x+0.0014$ & 0.99 & 0.0016 & 50.00 \\
\hline & Inhibitor & 0.002 & 0.001 & 0.001 & 0.001 & $y=0.00000005 x^{2}-0.00001 x+0.0016$ & 0.97 & 0.0011 & 100 \\
\hline
\end{tabular}

only from the urea treatment without inoculation, which achieved the values of $0.0021,0.0025,0.0021$ and 0.0016 mmol kg-1 MF, respectively (Table 7). The Source $\times$ Dose interaction revealed that the application of the $\mathrm{N}$ source with urease-inhibitor resulted in the best fit of the quadratic equation, with the maximum value of $0.003 \mathrm{mmol} \mathrm{kg}{ }^{-1} \mathrm{MF}$ obtained at the dose of $125 \mathrm{~kg} \mathrm{ha}^{-1} \mathrm{~N}$. Meanwhile, the use of the urea source did not fit any mathematical model, with an average of $0.002 \mathrm{mmol} \mathrm{kg}^{-1} \mathrm{MF}$ (Table 8).

The analysis of variance showed an interaction of Source $\times$ Inoculation $\times$ Dose (Table 3 ) for the variables Chl $\mathrm{b}$ and total Chl. Chl $b$ showed the best fit to the quadratic model, in which urea fertilization with the absence and presence of bacterial inoculation reached the maximum value of 0.00161 and $0.0009 \mathrm{mmol} \mathrm{kg}^{-1} \mathrm{MF}$ at the estimated doses of 65.16 and $71.42 \mathrm{~kg} \mathrm{ha}^{-1} \mathrm{~N}$, respectively, while the application of the source with urease inhibitor in the absence and presence of Azospirillum promoted the value of 0.00170 and $0.00200 \mathrm{mmol} \mathrm{kg}^{-1} \mathrm{MF}$ in the estimated dose of $100 \mathrm{~kg}$ $\mathrm{ha}^{-1} \mathrm{~N}$, respectively. The total $\mathrm{Chl}$ concentration was adjusted to the quadratic model, where it was observed that the application of urea with the absence and presence of Azospirillum resulted in a maximum content of 0.00363 and $0.0026 \mathrm{mmol} \mathrm{kg} \mathrm{kg}^{-1} \mathrm{MF}$ in the estimated dose of $75 \mathrm{~kg} \mathrm{ha}^{-1} \mathrm{~N}$, respectively, and the use of the urease inhibitor in the absence and presence of the bacteria obtained the maximum value of 0.00460 and $0.00563 \mathrm{mmol} \mathrm{kg}^{-1} \mathrm{MF}$ at the doses of 100 and $125 \mathrm{~kg} \mathrm{ha}^{-1} \mathrm{~N}$, respectively (Table 4).

In the case of carotenoids content, the analysis of variance indicated significant Inoculation $\times$ Dose and Source $\times$ Dose interactions (Table 3 ), and the treatment related to $\mathrm{N}$ fertilizer with absence of $A$. brasilense, adjusted 
to the quadratic regression model, in which the maximum concentration of $0.001 \mathrm{mmol} \mathrm{kg}^{-1} \mathrm{MF}$ was estimated at a dose of $64.28 \mathrm{~kg} \mathrm{ha}^{-1} \mathrm{~N}$ (Table 6). However, plants grown in soil fertilized with $\mathrm{N}$ inoculated with the bacteria showed a decreasing linear response, where the increase in $\mathrm{N}$ fertilization decreases the concentration of carotenoids per plant, reaching the value of 0.002 moll kg-1 $\mathrm{MF}$ with the lowest $\mathrm{N}$ dose. For the Source $\times$ Dose interaction, it presented the best fit to the quadratic model, with the highest value of 0.0016 and $0.0011 \mathrm{mmol} \mathrm{kg}^{-1} \mathrm{MF}$ obtained in the doses of 50 and $100 \mathrm{~kg} \mathrm{ha}^{-1} \mathrm{~N}$ for the source's urea and urease-inhibitor, respectively (Table 8).

\section{Discussion}

Increase in growth by inoculation of corn with A. brasilense may be associated with the production of growth hormones such as auxins, gibberellins and indoleacetic acid, excreted by the bacteria, which besides promoting the seed germination process, stimulates the plant growth through cell elongation (Vogel and Fey 2019). Similar trends were described by Costa et al. (2015) and Marini et al. (2015), who found a larger stem diameter in corn inoculated with Azospirillum, in comparison to the absence of the bacteria. The increment in the $\mathrm{N}$ fertilization, focusing on the $180 \mathrm{~kg}$ ha $^{-1} \mathrm{~N}$ dose associated with $A$. brasilense inoculation greatly increased stem diameter. The increase in stem diameter in corn is associated with the increase in production, since it allows the storage of soluble solids that will later be used during the grain formation phase (Fancelli and Dourado Neto 2000), mainly under stress condition that compromises the rate of production or translocation of photo-assimilates (Dartora et al. 2013).

Nitrogen fertilization at the correct dose and satisfying the nutritional requirements of the plants plays a fundamental role in the vegetative growth as well as in the production, as a result. The greater vegetative mass in plants fertilized with $\mathrm{N}$ and inoculated with $A$. brasilense, may be associated with the positive effect of $\mathrm{N}$ in some physiological processes of the plant, in addition to the greater $\mathrm{N}$ fixation and its stimulating action on plant growth (Kordi and Ghanbari 2019). Morais et al. (2015) identified that application of doses of 100 and $200 \mathrm{~kg} \mathrm{ha}^{-1} \mathrm{~N}$, promoted an increase in all vegetative attributes of corn, as justified by the importance of $\mathrm{N}$ for the crop, which is an essential macronutrient, responsible for amino acids, proteins, nitrogenous bases and nucleic acids biosynthesis. The results showed that the highest dose of $180 \mathrm{~kg} \mathrm{ha}^{-1} \mathrm{~N}$ was responsible for the highest accumulation of total dry matter in corn not inoculated with Azospirillum; in contrast, plants inoculated with the bacteria obtained maximum values in lower doses of $\mathrm{N}$, where the highest value of TDM of 89,08 and $83,12 \mathrm{~g} \mathrm{plant}^{-1}$ were obtained in doses of 186,89 and $159,28 \mathrm{~kg} \mathrm{ha}^{-1}$ de $\mathrm{N}$ with application of urea in the absence and presence of the bacteria, respectively. Because $\mathrm{N}$ is the main component of the chlorophyll molecule, amino acids and proteins, it allows the crop to grow until it reaches full maturity (Marngar and Dawson 2017), thus, the greater availability of $\mathrm{N}$ promotes an increase in the production of dry mass of corn (Bianchet et al. 2015). Early studiesinvolving inoculations between plants and Azospirillum reported that the benefit was essentially derived from biological $\mathrm{N}_{2}$ fixation; however, in later studies they identified a positive effect on the morphological and physiological changes in the roots of the inoculated plants (Okon and Vanderleyden 1997; Dobbelaere et al. 2001). Except for the growth-promoting hormone excretion, $\mathrm{N}$ increased absorption of water and nutrients (Reis et al. 2008), resulting in a greater dry mass production and assimilation of nutrients by inoculated plants.

A higher net photosynthesis in plants with the bacterium can be attributed to the process of $\mathrm{N}$ fixation and the secretory function of growth-regulator hormone (Kordi and Ghanbari 2019). Saikia et al. (2007) and Barassi et al. (2008), in a study of corn plants inoculated with Azospirillum observed an improvement in the photosynthetic parameters of the leaves, therefore, collaborating with the results of this work. The increasing doses of $\mathrm{N}$ may have promoted the increase in carboxylation, due to the need for the carbonic chain for the assimilation of nitrate (Dos Anjos Soares et al. 2013). Moreover, considering that corn was at full growth requires higher levels of carbon and $\mathrm{N}$, the increase in $\mathrm{N}$ availability enabled the increase in carboxylation (Jadoski et al. 2016). In addition, the rise in the concentration of $\mathrm{N}$ in the soil may have favored cell division and expansion, giving rise to a greater photosynthetically active area in the corn leaf (Marngar and Dawson 2017), since it is the N constituent of the components of the photosynthetic process, the increase results in an increase in the rate of carbon assimilation (Braz et al. 2019).

The improvement in stomatal conductance in corn plants inoculated with A. brasilense (Barassi et al. 2008) occurred due to a higher concentration of $\mathrm{CO}_{2}$ in the intercellular spaces and the rate of leaf $E$ (Rodrigues et al. 2014). According to Jadoski et al. (2016), stomatal conductance increased as the dose of $\mathrm{N}$ applied at $46 \mathrm{DAE}$ increased due to the greater carboxylation and the translocation of photo-assimilates promoted by the increment in the photosynthesis. Our results revealed approximately constant values, regardless of the factors analyzed (Tables 7 and 8), which presumably occurred because of the absence of water limitation during the experimental period since the test was maintained in the field capacity, thus, the corn plants expressed the maximum transpiration demand. Bulegon et al. (2016), reported that the soybean crop, the plant expressed the maximum transpiration demand under adequate water conditions.

The activities of $A$. brasilense in the root system and conducting vessels allow the high activity of the hormone auxin, thus allowing a greater vegetative growth in corn 
plants and a greater absorption and transport of water, supporting hydration and biochemical activity in plant tissues (Hungria et al. 2010; Masciarelli et al. 2013; Filippou et al. 2014; Cassán and Diaz-Zorita 2016). Taiz and Zeiger (2013) showed that rubisco is an enzyme considerable found in leaves, representing about $40 \%$ of the total soluble proteins; therefore, concentrations of carbon dioxide in intercellular spaces may infer in an indication of malfunction of the enzyme. In addition, a higher rate of net $\mathrm{CO}_{2}$ assimilation observed in this work is attributed to the increase in the concentration of $\mathrm{CO}_{2}$ in the intercellular spaces due to the increase in the $\mathrm{N}$ doses which ranged from 14.53 at zero doses (control) to $19.04 \mu \mathrm{mol} \mathrm{m}^{-2} \mathrm{~s}^{-1}$ at the dose of $180 \mathrm{~kg} \mathrm{ha}^{-1}$ of $\mathrm{N}$. Rodrigues et al. (2014) attributes that higher rates of net $\mathrm{CO}_{2}$ assimilation, stomatal conductance and leaf transpiration improve intercellular concentration of $\mathrm{CO}_{2}$ in leaves. Farquhar and Sharkey (1982) reported that an increase in the concentration of $\mathrm{CO}_{2}$ in the sub-stomatal chamber does not always provide an increase in the net $\mathrm{CO}_{2}$ assimilation rate by the plant, which is defined as the maximum carboxylation efficiency. Jadoski et al. (2016) found that the increase in the amount of carbon in corn plants occurred due to the full growth and development of corn, and thus requiring higher $\mathrm{CO}_{2}$ and $\mathrm{N}$ rates to compensate for the increase in carboxylation.

The increase in chlorophyll contents (Chl $a, b$ and total) was promoted by the increment in the $\mathrm{N}$ metabolism, as it is the fundamental nutrient in plants, directly participating in the protein and chlorophyll biosynthesis. As a result, the application of $\mathrm{N}$ increases the chlorophyll concentration in corn plants (Morais et al. 2015). The excess of $\mathrm{N}$ available to the plant is harmful, observing that in the highest dose of $\mathrm{N}\left(180 \mathrm{~kg} \mathrm{ha}^{-1} \mathrm{~N}\right)$ there was a reduction by $33 \%$ in Chl $a$ contents compared to the dose of $125 \mathrm{~kg} \mathrm{ha}^{-1} \mathrm{~N}$, possibly due to the directing of $\mathrm{N}$ for the formation of dry mass of plants, causing a dilution in the concentration of the nutrient (Larrosa et al. 2009). In addition, the decrease in the concentration of carotenoids with the increase in the $\mathrm{N}$, with the highest value of 0.0016 and $0.0011 \mathrm{mmol} \mathrm{kg}^{-1} \mathrm{MF}$ obtained in the doses of 50 and $100 \mathrm{~kg} \mathrm{ha}^{-1}$ of $\mathrm{N}$ for the sources urea and urease inhibitor, respectively, may have reduced the concentration of the chlorophylls, since the carotenoids in the leaves have the function of protecting the chlorophylls against degradation (Abdelgawad et al. 2015).

According to Dwyer et al. (1995), over-assimilated N accumulates in $\mathrm{NO}_{3}^{-}$, and in this way, $\mathrm{N}$ is not associated with the chlorophyll molecule, which partly explains the decrease observed in the concentration of this photosynthetic pigment as the availability of $\mathrm{N}$ increases (Takebe and Yoneyama 1989). In addition, the reductions in chlorophyll concentration indicate a reduction in the photosynthetic capacity of corn, which is related to the action of ribulose-1, 5-bisphosphate carboxylase/oxygenase (Rubisco), the protein most widely distributed in the plant kingdom in leaves (Taiz and Zeiger 2013).

\section{Conclusion}

The inoculation of corn seed with $A$. brasilense and $\mathrm{N}$ doses promoted an increase SD, LN, LDM, APDM e TDM, in addition to improving $A, g s$ and $E$. In general, the dose of $180 \mathrm{~kg} \mathrm{ha}^{-1}$ de $\mathrm{N}$ promoted increases in growth and gas exchange variables. The dose of $120 \mathrm{~kg} \mathrm{ha}^{-1}$ de $\mathrm{N}$ com $A$. brasilense favored the LN, LDM, APDM and improvement in $A$ and $g s$. The application of $\mathrm{N}$ with the urease inhibitor resulted in the largest $\mathrm{SD}, \mathrm{C} / / \mathrm{Ca}$ ratio, $\mathrm{E}$ and $\mathrm{Chl}$ a.

\section{Acknowledgments}

The authors would like to thank the Amazônia Foundation for Supporting the Studies and Research in the State of Pará (FAPESPA), the Federal Rural University of the Amazon and the Biodiversity Study Group of Higher Plants (EBPS), for the financial and structural support for the execution of this experiment.

\section{Author Contributions}

This work was carried out in collaboration with all authors. Authors JGP, RSO, GDPA and CFON elaborated the study, performed the statistical analysis, drafted the protocol and wrote the first draft of the manuscript. Authors MGN and DJPS wrote the manuscript. The authors, JSST, WRLLF and LCS analyzed the data, improving the final version of the manuscript. All authors read and approved the final manuscript.

\section{Conflict of Interest}

All authors declare no conflict of interest

\section{Data Availability}

Data presented in this study will be available on a fair request to the corresponding author.

\section{Ethics Approval}

Not applicable in this paper

\section{References}

Abdelgawad H, ER Farfan-Vignolo, D De Vos, H Asard (2015). Elevated $\mathrm{CO}_{2}$ mitigates drought and temperature induced oxidative stress differently in grasses and legumes. Plant Sci 231:1-10

Barassi CA, RJ Sueldo, CM Creus, LE Carrozzi, WM Casanovas, MA Pereyra (2008). Potencialidad de Azospirillum en optimizer el crecimiento vegetal bajo condiciones adversas. In: Azospirillum sp.: Cell Physiology, Plant Interactions and Agronomic Research in Argentina, pp:49-59. Cassán FD, I Garcia de Salamone (Eds.). Asociación Argentina de Microbiologia, Argentina

Braz RDS, CFD Lacerda, RND Assis Júnior, JFDS Ferreira, ACD Oliveira, ADA Ribeiro (2019). Growth and physiology of maize under water salinity and nitrogen fertilization in two soils. Rev Bras Engenharia Agríc Ambiental 23:907-913 
Bianchet PL, Sangoi, CAD Souza, O Klauberg Filho, F Panison (2015). Desenvolvimento vegetativo do arroz irrigado afetado pela inoculação com Azospirillum e aplicação de nitrogênio mineral. Rev Fac Agron 114:201-207

Bulegon LG, VF Guimarães, VA Egewarth, MG Santos, AL Heling, SD Ferreira, APGS Wengrat, AG Battistus (2016). Growth and gas exchange in the vegetative period of soy inoculated with bacteria diazotrophic. Nativa 4:277-286

Cantarella H, PCO Trivelin, TLM Contin, FLF Dias, R Rossetto, R Marcelino, RB Coimbra, JA Quaggio (2008). Ammonia volatilisation from urease inhibitor-treated urea applied to sugarcane trash blankets. Sci Agric 65:397-401

Cassán F, M Diaz-Zorita (2016). Azospirillum sp. in current agriculture: From the laboratory to the field. Soil Biol Biochem 103:117-130

Catuchi TA, HF Vítolo, SC Bertolli, GM Souza (2011). Tolerance to water deficiency between two soybean cultivars: Transgenic versus conventional. Ciência Rural 31:373-378

Coêlho JD (2018). Produção de grãos: Feijão, milho e soja. Cad Setorial Etene 3:1-13

Costa RRGF, GSF Quirino, DCF Naves, CB Santos, AFS Rocha (2015). Efficiency of inoculant with Azospirillum brasilense on the growth and yield of second-harvest maize. Pesq Agropec Trop 45:304-311

Dartora J, VF Guimaraes, D Marini, G Sander (2013). Nitrogen fertilization associated to inoculation with Azospirillum brasilense and Herbaspirillum seropedicae in the maize. Rev Bras Eng Agric Ambiental 17:1023-1029

De Oliveira IJ, J Fontes, J Barreto, J Pinheiro (2018). Recomendações técnicas para o cultivo de milho no Amazonas. Available at: https://www.infoteca.cnptia.embrapa.br/infoteca/bitstream/doc/1096 180/1/12018Final.pdf (Accessed: 13 March 2020)

Dobbelaere S, A Croonenborghs, A Thys, D Ptacek, J Vanderleyden, P Dutto, C Labandera-Gonzalez, J Caballero-Mellado, JF Aguirre, Y Kapulnik, S Brener, S Burdman, D Kadouri, S Sarig, Y Okon (2001) response of agronomically important crops to inoculation with Azospirillum. Aust J Plant Physiol 28:871-879

Dos Anjos Soares LA, GF Furtado, EMG Andrade, JRM Sousa, HOC Guerra, R Do Nascimento (2013). $\mathrm{CO}_{2}$ exchange of cowpea under saline water and nitrogen fertilization. Agropec Científica Semiárido 9:30-37

Dwyer LM, AM Anderson, BL Ma, DW Stewart, M Tollenaar E Gregorich (1995). Quantifying the nonlinearity in chlorophyll meter response to corn leaf nitrogen concentration. Can J Plant Sci 75:179-182

Embrapa (2018). Sistema Brasileiro de Classificação de solos. Revista e ampliada $5^{\text {a }}$ edição pp:1-355. Embrapa, DF, Brasília

Fancelli AL, D Dourado Neto (2000). Produção de Milho. Agropecuária, Guaíba, Brazil

Farquhar, G.D. and Sharkey, T.D. (1982) Stomatal conductance and photosynthesis. Anпи Rev Plant Physiol 33:317-345

Frazão JJ, AR da Silva, VL da Silva, VA Oliveira, RS Corrêa (2014). Fertilizantes nitrogenados de eficiência aumentada e ureia na cultura do milho. Rev Bras Engenharia Agríc Ambiental 18:1262-1267

Ferreira DF (2019). Sisvar: A computer analysis system to fixed effects split plot type designs. Rev Bras Biometria 37:529-535

Filippou P, P Bouchagier, E Skotti, V Fotopoulos (2014). Proline and reactive oxygen/nitrogen species metabolism is involved in the tolerant response of the invasive plant species Ailanthus altissima to drought and salinity. Environ Exp Bot 97:1-10

Galindo FS, MCM Teixeira Filho, S Buzetti, PH Pagliari, JMK Santini CJ Alves, MM Megda, TAR Nogueira, M Andreotti, O Arf (2019). Maize yield response to nitrogen rates and sources associated with Azospirillum brasilense. Agron J 111:1985-1997

Galindo FS, MCM Teixeira Filho, S Buzetti, JMK Santini, CJ Alves, LM Nogueira, MGZ Ludkiewicz, M Andreotti.and JLM Bellotte (2016). Corn yield and foliar diagnosis affected by nitrogen fertilization and inoculation with Azospirillum brasilense. Rev Bras Ciência Solo 40:15-36

Hungria M, RJ Campo, EM Souza, FO Pedrosa (2010). Inoculation with selected strains of Azospirillum brasilense and A. lipoferum improves yields of maize and wheat in Brazil. Plant Soil 331:413425
IFA (2019) International Fertilizer Industry Association. IFA database. Available at: http://www.fertilizer.org/. (Accessed: 17 March 2019)

Jadoski CJ, JD Rodrigues, D De Oliveira, DO Guilherme, EO Ono, RR Marques, SO Jadoski (2016). Physiological assessments of sweet sorghum inoculated with Azospirillum brasilense according to nitrogen fertilization and plant growth regulators. Intl $J$ Environ Agric Res 2:45-54

Köppen W (1918). Klassification der klimate nach temperatur, Niederschlag und Jahreslauf. Petermanns Geogr. Mitteilungen 64:193-203

Kordi S, F Ghanbari (2019). Evaluation of yield, yield components and some physiological and qualitative traits of corn affected by chemical and biological nitrogen fertilizers. Acta Sci Polonorum-hortorum Cultus 18:3-12

Larrosa, E Marchesan, LS Da Silva, LA De Avila (2009). Nitrogen doses and timing on rice susceptibility to low temperature in reproductive stage. Ciência Rural 39:992-998

Leite RC, AC Santos, JGD Santos, RC Leite, LBT Oliveira, M De Hungria (2019). Mitigation of Mombasa grass (Megathyrsus maximus) dependence on nitrogen fertilization as a function of inoculation with Azospirillum brasilense. Rev Bras Ciência do Solo 43:1-14

MariniD, VF Guimarães, J Dartora, MC Lana AS Pinto Júnior (2015). Growth and yield of corn hybrids in response to association with Azospirillum brasilense and nitrogen fertilization. Rev Ceres 62:117-123

Marngar E, J Dawson (2017). Effect of biofertilizers, levels of nitrogen and zinc on growth and yield of hybrid maize (Zea mays L.). Intl J Curr Microbiol Appl Sci 6:3614-362

Masciarelli O, L Urbani, H Reinoso, V Luna (2013). Alternative mechanism for the evaluation of indole-3-acetic acid (IAA) production by Azospirillum brasilense strains and its effects on the germination and growth of maize seedlings. J Microbiol 51:590-597

Morais TP, CH Brito, AS Ferreira JMQ Luz (2015) Morphophysiological aspects of maize plants and soil biochemistry due to nitrogen fertilization and maize seed inoculation with Azospirillum brasilense. Rev Ceres 62:507-514

Munareto JD, TN Martin, TM Muller, UR Nunes, GB Rosa, LFT Grando (2018). Compatibility of Azospirillum brasilense with fungicide and insecticide and its effects on the physiological quality of wheat seeds. Ciência Agraria 39:855-864

Okon Y, J Vanderleyden (1997). Root-associated Azospirillum species can stimulate plants. ASM News 63:364-370

Reis Júnior FB, CTT Machado, AT Machado, L Sodek (2008). Inoculation of Azospirillum amazonense Intwo maize genotypes under different n treatments. Rev Bras Ciência Solo 32:1139-1146

Ritchie SW, JJ Hanway, GO Benson (1993). How a Corn Plant Develops. Special Report No. 48. Iowa State University of Science and Technology, Ames, Iowa, USA

Rodrigues LFOS, F Guimarães, MB Da Silva, JAS Pinto, J Klein, ACPR Da Costa (2014). Agronomic characteristics of wheat as a function of Azospirillum brasilense, humic acids and nitrogen in a greenhouse. Rev Bras Engenharia Agríc Ambiental 18:31-37

Saikia SP, V Jain, K Sangeeta, A Samitha (2007). Dinitrogen fixation activity of Azospirillum brasilense in corn. Curr Sci 93:1296-1300

Sangoi L, A Schmitt, CG Zanin (2007). Área foliar e rendimento de grãos de híbridos de milho em diferentes populações de planta. Rev Bras Milho Sorgo 6:263-271

Sims DA, JA Gamon (2002). Relationships between leaf pigment content and spectral reflectance across a wide range of species, leaf structures and developmental stages. Remote Sens Environ 81:337-354

Silva FC (1999). Manual de Análises Químicas de Solos, Plantas e Fertilizantes. Comunicação para Transferência de Tecnologia, 370. Embrapa, Brasília

Souza EMFS, MCM Galindo, PRT Teixeira Filho, AC Silva, GC Santos, Fernandes (2019). Does the nitrogen application associated with Azospirillum brasilense inoculation influence corn nutrition and yield. Rev Bras Engenharia Agríc Ambiental 23:53-59

Sangoi L, AC Berns, ML Almeida, CG Zanim, C Schweitzer (2007) Agronomic characteristics of wheat cultivars in response to the time of nitrogen cover fertilization. Ciência Rural 37:1564-1570

Taiz L, Zeiger (2013). Plant Physiology $4^{\text {th }}$ edn. Sinauer Associates, Sunderland, Massachusetts, USA 
Takebe M, T Yoneyama (1989). Measurement of leaf colour scores and its implication to nitrogen nutrition of rice plants. Jpn Agric Res J 232:86-93

Vijayalakshmi NR, M Swamy, Mahadeva (2019). Morphological and biochemical characterization of Azospirillum isolates from rhizoplane of foxtail millet [Setaria italica (L.) Beauv.]. J Pharmcog Phytochem 8:114-118
Vogel GF, R Fey (2019). Azospirillum brasilense interaction effects with captan and thiodicarb on the initial growth of corn plants. $J$ Neotrop Agric 6:53-59

Vogel GF, R Fey (2016). Estímulo fazer potencial germinativo e fisiológico de centeio e triticale por Azospirillum brasilense, sub metidos ao tratamento químico de sementes. Sci Agraria Paranaenses 15:49349 